\section{Podagrion charybdis Fernando (Hymenoptera: Chalcidoidea: Torymidae) parasitic on ootheca of Tendodera fasciata (Olivier) (Insecta: Mantodea): first record from India and redescription}

\section{P.M. Sureshan}

Zoological Survey of India, Gangetic Plains Regional Station, Rajendra Nagar, Patna, Bihar 800016, India

Email: samanyu2003@yahoo.com

Abbreviations: F1-F7 - Funicular segments 1 to 7; OOL - Ocellocular distance; POL - Postocellar distance; SMV -Sub marginal vein; MV Marginal vein; PMV - Post marginal vein; STV - Stigmal vein.

Podagrion charybdis Fernando was described from Sri Lanka based on specimens reared from ootheca of praying mantids. The holotype was not designated by the author and the original description was based on 14 females and six males (syntypes). Narendran (1994) and Grissell (1995) treated this species and mentioned the probable loss of the syntypes. While rearing the ootheca of a mantid collected from the Kendrapara district of Orissa, 44 female and 12 male specimens of Podagrion emerged along with seven mantid nymphs. On detailed study it was revealed that the parasitoids belong to the species Podagrion charybdis Fernando (Chalcidoidea: Torymidae) and the nymphs belong to the species Tenodera fasciata (Olivier) (Mantodea: Mantidae: Mantinae: Mantini). The parasitoid was identified following its original description, the only available data on the species. The mantid host was identified following Mukerjee et al. (1995). Since the original description of Podagrion charybdis is inadequate, a detailed redescription of the species is provided here based on the specimens studied. This forms the first record of the species from India and the first time it is being reported subsequent to the original description. The specimens of the present study are deposited in the Zoological

Date of publication 26 April 2009

ISSN 0974-7907 (online) | 0974-7893 (print)

Editor: T.C. Narendran

Manuscript details:

Ms \# 01887

Received 16 November 2007

Final received 26 March 2008

Finally accepted 01 April 2008

Citation: Sureshan, P.M. (2009). Podagrion charybdis Fernando (Hymenoptera: Chalcidoidea: Torymidae) parasitic on ootheca of Tendodera fasciata (Olivier) (Insecta: Mantodea): first record from India and redescription. Journal of Threatened Taxa 1(4): 234-235.

Copyright: (C) Sureshan, P.M. 2009. Creative Commons Attribution 3.0 Unported License. JoTT allows unrestricted use of this article in any medium for nonprofit purposes, reproduction and distribution by providing adequate credit to the authors and the source of publication.

Acknowledgements: I am grateful to the Director, Zoological Survey of India, Kolkatta and the Officer-in-charge, Zoological Survey of India, Estuarine Biological Station, Gopalpur-on-sea for providing facilities.

OPEN AGCESS | FREE DOWNLOAD
Survey of India, Gangetic Plains Regional Station, Bihar (ZSIP).

\section{Podagrion charybdis Fernando}

(Figs. 1- 5)

1957. Podagrion charybdis Fernando. Ceylon j.Sci. 217. 14 Females, 8 male syntypes, Matale Dist., Gammadua, Sri Lanka (Syntypes probably lost?)

Material examined: 44 Females, 12 males, 13.iii.2007, $20^{\circ} 35^{\prime} \mathrm{N}$ \& $86^{\circ} 30^{\prime} \mathrm{E}$, ex. Ootheca of mantid Tenodera fasciata (Olivier), Indupur, Dhumata village, Kendrapara district, Orissa, India coll. P.M. Sureshan, Reg. No. A.1240.

\section{Redescription}

Female: Body 3.1-3.3 mm, ovipositor 3.6-4mm. Head and thorax metallic greenish-blue; antennae testaceous, club brown; fore and hind coxae and hind femora concolorous with thorax; mid coxae and remainder of legs brown with tarsi paler; tegulae testaceous, wings hyaline, veins testaceous.

Head: Slightly wider than thorax $(1.05 \mathrm{x})$, in dorsal view $1.8 \mathrm{x}$ as broad as long and $1.2 \mathrm{x}$ as broad as high in front view; sculpture finely reticulate punctuate, striate reticulate on lower face, reticulation finer on gena; occiput margined, carina fine; POL 4x OOL; interocellar area little raised; anterior margin of clypeus straight; malar space $0.4 \mathrm{x}$ as long eye, eye separated little less than their individual height. Antennae (Fig. 1) inserted below middle of face, scape not reaching median ocellus, $0.6 \mathrm{x}$ eye length and $3 \mathrm{x}$ as long as broad, pedicelllus plus flagellum $1.4 \mathrm{x}$ as long as head width, anellus transverse, F1 little shorter than pedicel, F2 slightly longer than F1, F3 as long as F1, F4 little shorter than F1, F5-F7 equal and little shorter than F4, F1-F3 with three irregular rows of small sensillae, other segments with two rows of sensillae; club almost equal to five preceding segments combined, area of micropilosity reaching base, sutures hardly visible.

Thorax: Length $2.1 \mathrm{x}$ width, uniformly and distinctly reticulate, meshes small, pubescence small, moderately dense. Pronotal collar not margined. Mesoscutum $1.8 \mathrm{x}$ as broad as long, notauli fine, almost complete. Scutellum less convex, finely reticulate, frenal area more or less shiny, apical margin with a row of small foveae, median length little shorter than mesocutum (9:10). Dorsellum smooth. Propodeum with median length as long as scutellum, uniformly and moderately reticulate with an inverted ' $\mathrm{V}$ ' shaped carina, base of ' $\mathrm{V}$ ' not reaching base of propodeum, join with irregular longitudinal rugae at the base, spiracles elongate, oval. Metapleuron shiny. Mesepimeron shiny with deep foveae in the middle. Mesepisternum moderately reticulate. Prepectus finely reticulate. Hind femora (Fig. 2 ) finely reticulate with six teeth, second tooth small (in some specimens 2 nd tooth not small). Forewing length $3 \mathrm{x}$ width, basal part bare, speculum and basal cell closed below, basal hairline indicated. Relative lengths SMV: 21, MV 11.5, PMV 2.5, STV 1.25.

Gaster: Petiole short, gaster including petiole slightly longer than thorax and $0.81 \mathrm{x}$ as long as head plus thorax combined, ovipositor $2.63 \mathrm{x}$ as long as gaster and $1.2 \mathrm{x}$ length of body.

Male: Length: $3.1-3.8 \mathrm{~mm}$. Similar to female except for the slender antenna, short gaster and hind leg longer with femora 


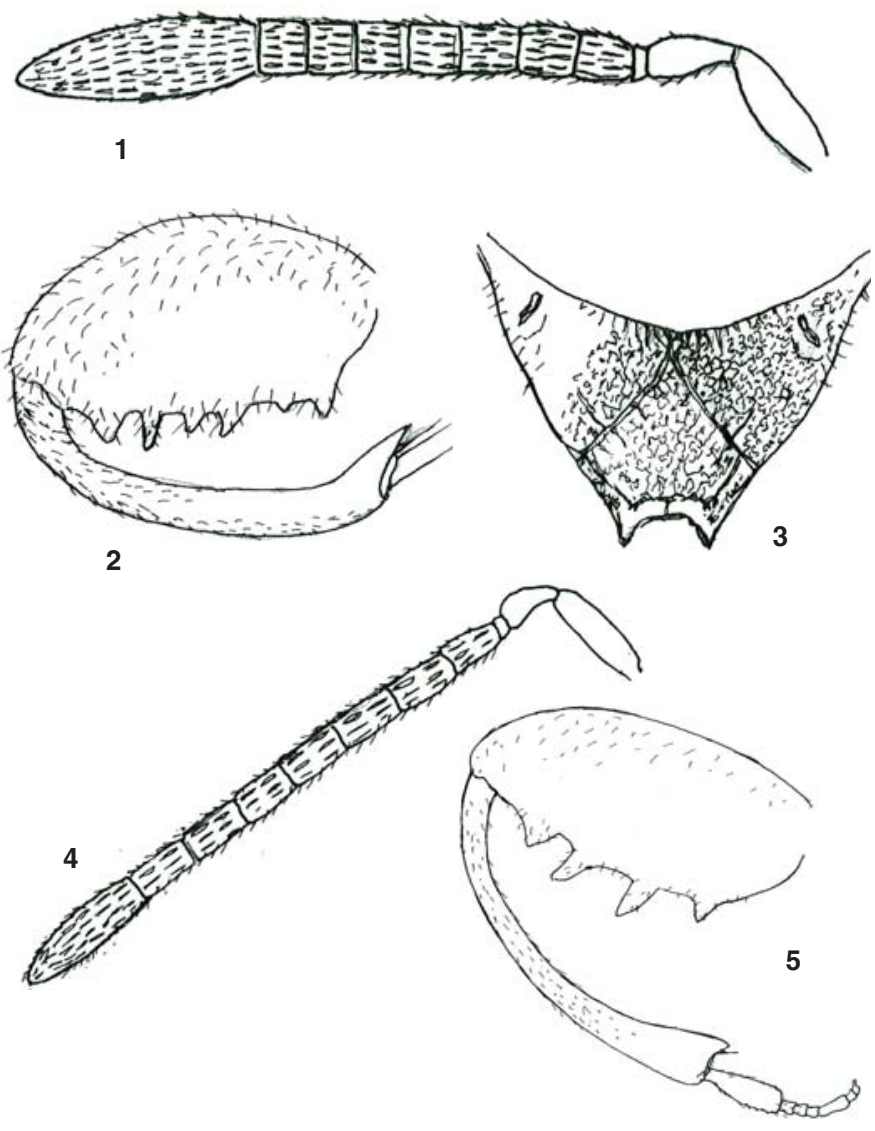

Figures 1-5. Podagrion charybdis Fernando

1 - female antenna; 2 - hind femur and tibia; 3 - propodeum dorsal view; 4 - male antenna; 5 - male hind leg (except coxa)

having four teeth, first tooth smaller.

\section{Biology}

Emerged from the ootheca of Tenodera fasciata (Olivier) (Mantodea: Mantidae). The ootheca oval and almost heart shaped having length $20 \mathrm{~cm}$ and maximum width $16 \mathrm{~cm}$ with a conical projection, collected from tall wild grass attached to the leaf blade. Fifty-six parasitoids (44 females and 12 males) and seven mantid nymphs emerged from the ootheca through emergence holes made on the ventro-lateral sides. Three male parasitoids emerged from the ootheca after 11 days of its collection from the field, followed by eight males and 33 females on the next day and 11 females and one male along with seven mantid nymphs after two days. If the total number of eggs inside the ootheca is taken as 63 (total emergences) percentage of parasitism is $88.9 \%$.

\section{Remarks}

This is the first record of Podagrion charybdis Fernando from India and the subsequent report of the species since its original description in 1957. The identity of the specimens was fixed based on the small description and comparatively good illustrations given by Fernando (1957). Slight variations in the comparative lengths of antennal segments in the current specimens from the original illustration may be considered due to minor error in drawing. P. charybdis closely resembles $P$.judas Fernando and P. scylla Fernando both described from Sri Lanka,

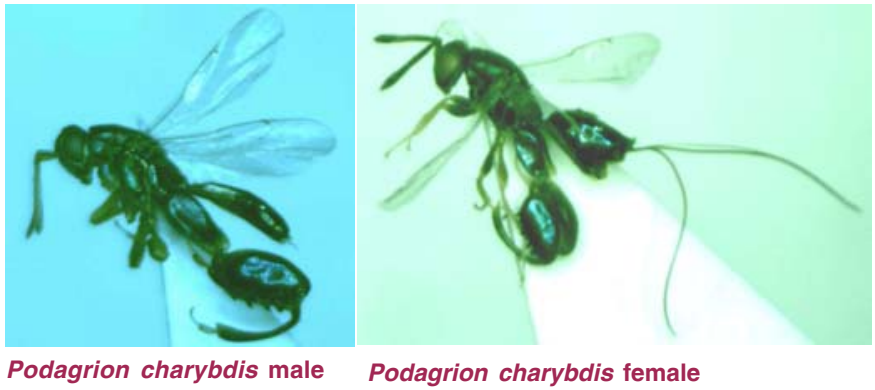

but differs mainly in the nature of antenna. Since the primary type material of all the three species are lost (Narendran 1994; Grissell 1995), it is very difficult to judge the exact identity of the present specimens. However, based on detailed examination of specimens and evaluation of characters they are identified here as $P$. charybdis.

\section{References}

Fernando, W. (1957). Contributions to a knowledge of the insects of Ceylon. 5 new parasitic Hymenoptera (Chalcidoidea). Ceylon Journal of Science 25: 209-219.

Grissell, E.E. (1995). Toryminae (Hymenoptera: Chalcidoidea: Torymidae) A Redefinition, Generic Classification and Annotated World catalog of Species. Memoirs on Entomology, International 2, 470pp.

Mukherjee,T.K., A.K. Hazra. \& A.K. Ghosh (1995). The mantid fauna of India (Insecta : Mantodea). Oriental Insects 29: 185-358.

Narendran, T.C. (1994). Torymidae and Eurytomidae of Indian Subcontinent. Zoological Monograph. Department of Zoology, University of Calicut, 500pp. 